\title{
A Value Co-creation Perspective on Information Systems Analysis and Design
}

\author{
Kazem Haki - Michael Blaschke - Stephan Aier • \\ Robert Winter
}

Received: 8 November 2016/Accepted: 14 August 2018/Published online: 6 September 2018

(C) Springer Fachmedien Wiesbaden GmbH, part of Springer Nature 2018

\begin{abstract}
Information systems analysis and design (ISAD) ensures the design of information systems (IS) in line with the requirements of a business environment. Since ISAD approaches follow the currently dominant logic of business, the rise of a new and thriving business logic may require revisiting and advancing extant ISAD approaches and techniques. One of the prevailing debates in marketing research is the paradigmatic shift from a goods-dominant (G-D) to a service-dominant (S-D) logic of business. The cornerstone of this reorientation is the concept of value cocreation emphasizing joint value creation among a variety of actors within a business network. With the aim of introducing value co-creation as a new discourse to ISAD research, this research note argues that (1) the lens of S-D logic with its core concept of value co-creation provides a novel perspective to ISAD. The authors also assert that (2) value co-creation-informed IS design realizes the paradigmatic shift from G-D to S-D logic. Building on this mutual relationship between value co-creation and ISAD, they propose a research agenda and discuss the ISAD artifacts that prospective research may target.
\end{abstract}

Accepted after three revisions by Ulrich Frank.

Kazem Haki and Michael Blaschke had the same contribution.

K. Haki $\cdot$ M. Blaschke $(\bowtie) \cdot S$. Aier $\cdot$ R. Winter

Institute of Information Management, University of St. Gallen,

Müller-Friedberg-Strasse 8, 9000 St. Gallen, Switzerland

e-mail: michael.blaschke@unisg.ch

K. Haki

e-mail: kazem.haki@unisg.ch

S. Aier

e-mail: stephan.aier@unisg.ch

R. Winter

e-mail: robert.winter@unisg.ch
Keywords Information systems analysis and design · Service-dominant logic $\cdot$ Value co-creation $\cdot$ Research agenda

\section{Introduction}

Information systems analysis and design (ISAD) is one of the most classical fields of research that arguably lies in the core of information systems (IS) research (Necco et al. 1987; Wand and Weber 1993; Iivari et al. 2006; Sidorova et al. 2008; Siau and Rossi 2011). While IS analysis aims to systematically capture the logic and identify requirements of the respective business environment, IS design intends to provide IS solutions that fit the business environment and that address the identified requirements. Thus, ISAD comprises sequential, iterative, or agile processes and activities of linking analysis and design phases in IS development endeavors (Recker et al. 2011; Wang and Wang 2012).

Business environments are conceptualized, analyzed, designed, and managed following a dominant logic of how a business ought to perform (Vargo and Lusch 2004). ISAD approaches should thereby account for requirements of the business environment's dominant logic. If the dominant logic of business undergoes a fundamental shift due to, for example, changes in market or business practices, ISAD approaches need to be revisited accordingly. This is due to the fact that a novel business logic requires to rethink the way a business environment is conceptualized, and the way IS for supporting such a business environment should be consequently analyzed and designed.

Recently, marketing studies (Vargo and Lusch 2004,2008 , 2016) have given rise to a ground-breaking paradigm shift from a goods-dominant (G-D) to a service- 
Table 1 S-D Logic's Fundamental Concepts

\begin{tabular}{|c|c|}
\hline Concept & Definition/explanation \\
\hline Resource & $\begin{array}{l}\text { "Resources are a function of how something (tangible or intangible) is or can be used, and not a function of things per se" } \\
\text { (Lusch and Nambisan 2015, p. 159) }\end{array}$ \\
\hline Operand resources & $\begin{array}{l}\text { Tangible and static (e.g., natural) resources that an actor acts on to obtain support (i.e., resources enable or facilitate) (Vargo } \\
\text { and Lusch 2004) }\end{array}$ \\
\hline Operant resources & $\begin{array}{l}\text { Intangible and dynamic (e.g., human skill) resources that act on other resources to produce effects rather than being } \\
\text { operated on (i.e., resources initiate or trigger) (Vargo and Lusch 2004) }\end{array}$ \\
\hline $\begin{array}{l}\text { Resource } \\
\text { integrator }\end{array}$ & $\begin{array}{l}\text { All social and economic actors are resource integrators in a network of other actors, and thus all actors are potential } \\
\text { innovators or co-creators of value (Lusch and Nambisan 2015) }\end{array}$ \\
\hline Offeror & Actors that make offers of resources or service to other actors. \\
\hline Beneficiary & Actors that benefit from other actors that supply them with service or resources. \\
\hline $\begin{array}{l}\text { Service } \\
\text { Ecosystem }\end{array}$ & $\begin{array}{l}\text { "A relatively self-contained, self-adjusting system of mostly loosely coupled social and economic (resource integrating) } \\
\text { actors connected by shared institutional logics and mutual value creation through service exchange" (Lusch and } \\
\text { Nambisan } 2015, \text { p. 162) }\end{array}$ \\
\hline Service system & $\begin{array}{l}\text { Dynamic configurations of resources that interact with other service systems to (co-)create mutual value (Maglio et al. } \\
\text { 2009) }\end{array}$ \\
\hline Service exchange & $\begin{array}{l}\text { Service is exchanged between service systems to access, adapt, and integrate resources among various service systems } \\
\text { (Edvardsson et al. 2011) }\end{array}$ \\
\hline Service platform & $\begin{array}{l}\text { "A modular structure that consists of tangible and intangible components (resources) and facilitates the interaction of actors } \\
\text { and resources (or resource bundles)" (Lusch and Nambisan 2015, p. 166) }\end{array}$ \\
\hline $\begin{array}{l}\text { Tangible } \\
\text { component }\end{array}$ & $\begin{array}{l}\text { Tangible and static components of goods "are seen as vehicles for service provision, rather than primary to exchange and } \\
\text { value creation" (Pels and Vargo 2009, p. 374) }\end{array}$ \\
\hline $\begin{array}{l}\text { Intangible } \\
\text { component }\end{array}$ & $\begin{array}{l}\text { "Bundled set of specialized knowledge and skills appearing in the form of intangible and dynamic components in extension } \\
\text { to goods" (Lusch and Nambisan 2015, p. 166) }\end{array}$ \\
\hline Value co-creation & $\begin{array}{l}\text { "The processes and activities that underlie resource integration and incorporate different actor roles in the service } \\
\text { ecosystem" (Lusch and Nambisan 2015, p. 162) }\end{array}$ \\
\hline Value-in-use & $\begin{array}{l}\text { "The customer's experiential evaluation of the product or service proposition beyond its functional attributes and in } \\
\text { accordance with his/her individual motivation, specialized competences, actions, processes, and performances" (Ranjan } \\
\text { and Read 2016, p. 293) }\end{array}$ \\
\hline
\end{tabular}

dominant (S-D) business logic. As opposed to the value-inexchange determination of G-D logic (i.e., value is created when goods are exchanged from a provider to a customer), $\mathrm{S}-\mathrm{D}$ logic emphasizes that value is determined by a customer on the basis of value-in-use (i.e., value is created jointly with customers when customers use goods and perceive them as useful) (Vargo and Lusch 2004, 2008). This paradigm shift moves the locus of value creation from exchange to use (Vargo and Lusch 2008). Therefore, the cornerstone of S-D logic is the concept of value co-creation (e.g., Galvagno and Dalli 2014; Vargo and Lusch 2016; Ranjan and Read 2016) in that value is determined by the quality of a value-in-use experience and not just by the quality of the provider's goods (Prahalad and Ramaswamy 2004). An example frequently referred to is RollsRoyce, a global market leader for professional power systems. Rolls-Royce has initiated a value co-creation orientation through selling jet turbine utilization (value-in-use, S-D logic) instead of selling jet turbine possession (valuein-exchange, G-D logic) (Neely 2008; Fichman et al. 2014; Barrett et al. 2015). Although this shift may seem marginal, it has in fact fundamental consequences on internal (e.g., product design, contracts) and external (e.g., transactions with customers and suppliers) business functions and requirements. Owing to this paradigmatic shift in conceptualizing economic exchange in the business environment, ISAD scholars may need to examine whether extant ISAD approaches, methods, and techniques can adequately capture novel business requirements and eventually reflect them in the design of IS. In the jet turbine case, the main question is how and whether existing prevalent IS - as results of extant ISAD approaches - can adequately support, for example, the underpinning processes, activities, and continuous business interactions to co-create value among various business actors in the respective ecosystem.

Building on the theoretical foundations of S-D logic and its core concept of value co-creation, the research note at hand aims to introduce a new perspective to ISAD research. We promote a discourse within the IS community and outline a research agenda on how this novel business logic can be reflected in ISAD research. To this end, we spotlight a mutual relationship between value co-creation 
Table 2 ISAD research streams (Iivari et al. 2000, 2004)

\begin{tabular}{|c|c|c|c|c|}
\hline Stream & ISAD paradigms & ISAD approaches & ISAD methods & ISAD techniques \\
\hline Definition & $\begin{array}{l}\text { Underlying philosophical } \\
\text { assumptions (ontology, } \\
\text { epistemology, } \\
\text { methodology, and ethics) } \\
\text { that guide the interpretation } \\
\text { of reality during ISAD }\end{array}$ & $\begin{array}{l}\text { A set of related common } \\
\text { features (goals, guiding } \\
\text { principles, and fundamental } \\
\text { concepts), shared by a class } \\
\text { of specific ISAD methods, } \\
\text { that drive interpretations } \\
\text { and actions in ISAD }\end{array}$ & $\begin{array}{l}\text { A set of goal-oriented } \\
\text { procedures that guide the } \\
\text { work of the various } \\
\text { stakeholders involved in } \\
\text { ISAD. Each ISAD method } \\
\text { represents a set of concepts, } \\
\text { beliefs, values, and } \\
\text { normative principles, which } \\
\text { are organized in a detailed } \\
\text { process. }\end{array}$ & $\begin{array}{l}\text { Well-defined procedures that } \\
\text { guarantee the achievement } \\
\text { of certain outcomes if } \\
\text { executed adequately. } \\
\text { Techniques may be } \\
\text { reusable across different } \\
\text { ISAD methods, i.e., they } \\
\text { create outcome } \\
\text { components rather than } \\
\text { complex outcomes. }\end{array}$ \\
\hline Exemplars & $\begin{array}{l}\text { Functionalism, social } \\
\text { relativism (interpretivism), } \\
\text { radical structuralism, and } \\
\text { neo-humanism (radical } \\
\text { humanism) }\end{array}$ & $\begin{array}{l}\text { Structured, object-oriented, } \\
\text { agile, information modeling, } \\
\text { interactionist, socio- } \\
\text { technical, open source }\end{array}$ & $\begin{array}{l}\text { Structured analysis and } \\
\text { design, object-oriented } \\
\text { analysis and design, object- } \\
\text { oriented software } \\
\text { engineering, rational unified } \\
\text { process, information } \\
\text { systems work and analysis } \\
\text { of changes, modern } \\
\text { structured analysis }\end{array}$ & $\begin{array}{l}\text { Data flow diagram, entity } \\
\text { relationship diagram, state } \\
\text { transition diagram, use } \\
\text { case, future workshop, pair } \\
\text { programming, conceptual } \\
\text { model, requirements } \\
\text { backlog, UML, mockup }\end{array}$ \\
\hline $\begin{array}{l}\text { Selected } \\
\text { literature }\end{array}$ & $\begin{array}{l}\text { Burrell and Morgan (1979), } \\
\text { Hirschheim and Klein } \\
\text { (1989, 1992), Iivari (1991), } \\
\text { Hirschheim et al. (1995), } \\
\text { 1996), Iivari et al. } \\
\text { (1998, 2000), and Waller } \\
\text { et al. (2008) }\end{array}$ & $\begin{array}{l}\text { Olerup (1989), Iivari (1991). } \\
\text { Bansler and Bødker (1993), } \\
\text { Iivari et al. (1998, 2000), } \\
\text { Warren and Adman (1999), } \\
\text { Ba et al. (2001), Wand and } \\
\text { Weber (2002), Lamb and } \\
\text { Kling (2003), Neus and } \\
\text { Scherf (2005), Avital and } \\
\text { Te'eni (2009), and } \\
\text { Germonprez et al. (2011) }\end{array}$ & $\begin{array}{l}\text { Yourdon (1988), Sircar et al. } \\
\text { (2001), Vidgen (2002), } \\
\text { Alter (2004), Janssen } \\
\text { (2006), Siponen et al. } \\
\text { (2006), and Dietz and } \\
\text { Juhrisch (2012) }\end{array}$ & $\begin{array}{l}\text { Wand and Weber (1993), } \\
\text { Rugg et al. (2002), } \\
\text { Grünbacher et al. (2004), } \\
\text { Hickey and Davis (2004), } \\
\text { Albert et al. (2004), Hadar } \\
\text { and Soffer (2006), Fonseca } \\
\text { and Martin (2007), Recker } \\
\text { et al. (2011), Siau and } \\
\text { Rossi (2011), Allen and } \\
\text { March (2012), and Frank } \\
2013\end{array}$ \\
\hline $\begin{array}{l}\text { Exemplary } \\
\text { discourses }\end{array}$ & $\begin{array}{l}\text { Comparative analysis of ISAD } \\
\text { paradigms (e.g., } \\
\text { Hirschheim and Klein } \\
\text { 1989) } \\
\text { Epistemology in ISAD (e.g., } \\
\text { Waller et al. 2008) }\end{array}$ & $\begin{array}{l}\text { Specific ISAD approaches } \\
\text { (e.g., Bansler and Bødker } \\
\text { 1993) } \\
\text { Future directions of ISAD } \\
\text { approaches (e.g., Avital and } \\
\text { Te'eni 2009) } \\
\text { Comparative analysis of ISAD } \\
\text { approaches (e.g., Iivari et al. } \\
\text { 1998) }\end{array}$ & $\begin{array}{l}\text { Specific methods (e.g., Dietz } \\
\text { and Juhrisch 2012) } \\
\text { Comparative analysis of ISAD } \\
\text { methods (e.g., Sircar et al. } \\
\text { 2001) }\end{array}$ & $\begin{array}{l}\text { Specific techniques (e.g., Siau } \\
\text { and Rossi 2011) } \\
\text { Conceptual modeling (e.g., } \\
\text { Frank 2013) } \\
\text { Cognitive views on ISAD } \\
\text { techniques (e.g., Browne } \\
\text { and Parsons 2012) }\end{array}$ \\
\hline $\begin{array}{l}\text { S-D logic } \\
\text { and value } \\
\text { co-creation } \\
\text { implications }\end{array}$ & $\begin{array}{l}\text { S-D logic/value co-creation hol } \\
\text { assumptions about economic } \\
\text { environments, which IS are } \\
\text { S-D logic/value co-creation off } \\
\text { complementary and new ISAL } \\
\text { environments' new goals, gui } \\
\text { fundamental concepts }\end{array}$ & $\begin{array}{l}\text { ds specific paradigmatic } \\
\text { exchange and business } \\
\text { atended to support. } \\
\text { ers a new lens to inform } \\
\text { approaches entailing business } \\
\text { ding principles, and }\end{array}$ & \multicolumn{2}{|c|}{$\begin{array}{l}\text { S-D logic-/value co-creation-informed ISAD approaches } \\
\text { require extended or new ISAD methods and techniques to } \\
\text { account for new goals (e.g., service-for-service exchange), } \\
\text { new guiding principles and believes (e.g., S-D logic's } \\
\text { foundational premises), as well as new fundamental concepts } \\
\text { (e.g., service ecosystem, service platform, resource } \\
\text { integrator, value co-creation) }\end{array}$} \\
\hline
\end{tabular}

and $I S A D$, based on which we call for future research. We posit that (1) value co-creation - from an S-D logic perspective - offers a novel lens to rethink the way a business and its corresponding IS are analyzed and designed, and that, in turn, (2) building IS development on S-D logic and value co-creation-informed ISAD facilitates the practical implementation of value co-creation. The latter thereby lays emphasis on the role of IS in materializing the paradigmatic shift from G-D to S-D logic.
In the following we first synthesize existing knowledge on S-D logic and value co-creation, which primarily originates from marketing research. This is followed by a discussion on ISAD's main research streams as well as on the role of S-D logic and value co-creation in ISAD. Eventually, through a value co-creation perspective, we propose a research agenda for advancing extant discourses in ISAD. The paper concludes with a discussion of the immediate contributions that prospective ISAD research may target. 
Table 3 Agenda for immediately required ISAD artifacts

\begin{tabular}{|c|c|c|c|}
\hline Target artifact & Description & Purpose & State of the art \\
\hline \multicolumn{4}{|c|}{ How does the lens of S-D logic and value co-creation inform ISAD? } \\
\hline $\begin{array}{l}\text { Value co- } \\
\text { creation } \\
\text { glossary }\end{array}$ & $\begin{array}{l}\text { A value co-creation glossary } \\
\text { enumerates, defines, and illustrates } \\
\text { constructs that are specific to the S-D } \\
\text { logic and value co-creation domain } \\
\text { (Kishore et al. 2004, p. 172). }\end{array}$ & $\begin{array}{l}\text { Unambiguous understanding of value } \\
\text { co-creation's semantics, use, and } \\
\text { foundations }\end{array}$ & $\begin{array}{l}\text { Galvagno and Dalli (2014), Vargo and } \\
\text { Lusch (2016, 2017), Ranjan and } \\
\text { Read (2016), Wilden et al. (2017) }\end{array}$ \\
\hline $\begin{array}{l}\text { Value co- } \\
\text { creation } \\
\text { ontology }\end{array}$ & $\begin{array}{l}\text { A value co-creation ontology structures } \\
\text { and codifies knowledge about the } \\
\text { concepts, relationships, and } \\
\text { axioms/constraints pertaining to the } \\
\text { value co-creation domain (Kishore } \\
\text { et al. 2004). }\end{array}$ & $\begin{array}{l}\text { Facilitating ontology-driven ISAD } \\
\text { grounded in value co-creation }\end{array}$ & $\begin{array}{l}\text { Annamalai et al. 2011, Fragidis and } \\
\text { Tarabanis (2011), Lemey and Poels } \\
\text { (2011), Mora et al. (2011), Gailly } \\
\text { et al. (2016) }\end{array}$ \\
\hline $\begin{array}{l}\text { Value co- } \\
\text { creation } \\
\text { modeling } \\
\text { language }\end{array}$ & $\begin{array}{l}\text { A value co-creation modeling language } \\
\text { facilitates building a conceptual } \\
\text { model of the domain that IS are } \\
\text { intended to support (Clarke et al. } \\
\text { 2016, p. 365). }\end{array}$ & $\begin{array}{l}\text { Analyzing, communicating, and } \\
\text { documenting requirements of the } \\
\text { value co-creation domain }\end{array}$ & $\begin{array}{l}\text { Yu and Mylopoulos (1994), Gordijn } \\
\text { and Akkermans (2003), } \\
\text { Matulevičius et al. (2007), Frank } \\
\text { (2013) }\end{array}$ \\
\hline $\begin{array}{l}\text { Value co- } \\
\text { creation case } \\
\text { database }\end{array}$ & $\begin{array}{l}\text { A value co-creation case database } \\
\text { facilitates public collection of and } \\
\text { access to empirical instances of } \\
\text { service exchange and value co- } \\
\text { creation processes in the form of case } \\
\text { surveys (Larsson 1993) }\end{array}$ & $\begin{array}{l}\text { Detailed empirical evidence and } \\
\text { analysis of value co-creation in } \\
\text { different contexts }\end{array}$ & $\begin{array}{l}\text { Baron and Warnaby (2011), McColl- } \\
\text { Kennedy et al. (2012), Aarikka- } \\
\text { Stenroos and Jaakkola (2012), } \\
\text { Jaakkola and Alexander (2014), } \\
\text { Sharma and Conduit (2016), Beirão } \\
\text { et al. (2017) }\end{array}$ \\
\hline \multicolumn{4}{|c|}{ How does ISAD realize the shift to $S-D$ logic and value co-creation? } \\
\hline $\begin{array}{l}\text { IS-enabled value } \\
\text { co-creation case } \\
\text { database }\end{array}$ & $\begin{array}{l}\text { An IS-enabled value co-creation case } \\
\text { database facilitates public collection } \\
\text { of and access to empirical instances } \\
\text { of IS-enabled value co-creation in } \\
\text { the form of case surveys (Larsson } \\
\text { 1993) }\end{array}$ & $\begin{array}{l}\text { Detailed empirical evidence and } \\
\text { analysis of digital service platforms } \\
\text { as well as IS-enabled service } \\
\text { ecosystems, service integration, and } \\
\text { value co-creation; providing a basis } \\
\text { to inform new ISAD artifacts }\end{array}$ & $\begin{array}{l}\text { Ceccagnoli et al. (2012), Han et al. } \\
\text { (2012), Sarker et al. (2012), } \\
\text { Breidbach and Maglio (2016) }\end{array}$ \\
\hline $\begin{array}{l}\text { Design } \\
\text { principles for } \\
\text { value co- } \\
\text { creation- } \\
\text { enabling is } \\
\text { instances }\end{array}$ & $\begin{array}{l}\text { Design principles for value co-creation- } \\
\text { enabling IS instances enumerate } \\
\text { requirements for the design and } \\
\text { sustainable growth of such systems } \\
\text { with regard to their specificities }\end{array}$ & $\begin{array}{l}\text { Understanding specificities of IS } \\
\text { instances (e.g., digital platforms) } \\
\text { that are a central point of gravity } \\
\text { within networked service } \\
\text { ecosystems and enable value co- } \\
\text { creation among actors in service } \\
\text { ecosystems; providing a set of } \\
\text { design principles with regard to } \\
\text { specificities of such IS instances }\end{array}$ & $\begin{array}{l}\text { Tilson et al. (2010), Henfridsson and } \\
\text { Bygstad (2013), Eaton et al. (2015), } \\
\text { Tan et al. (2015), and Reuver et al. } \\
\text { (2017) }\end{array}$ \\
\hline
\end{tabular}

\section{Service-Dominant Logic and Value Co-creation}

The S-D logic discussion has gained momentum since its inception by the landmark study of Vargo and Lusch (2004) in marketing research. This study promotes S-D logic in distinction to G-D logic. The latter is well reflected in neoclassical industrial perspectives as well as in our current understanding and analysis of business environments (Akaka and Vargo 2014, p. 371).

To develop a comprehensive conceptual foundation, Vargo and Lusch (2004) proposed, and further advanced (Vargo and Lusch 2008, 2016), a set of foundational premises for S-D logic. Building on these foundational premises, S-D logic re-conceptualizes the notions of service (applying specialized competencies for the benefit of another actor), economic exchange (not the exchange of outputs but the exchange of the performance of specialized activities), and value (occurs when the offering is useful to the customer) (Lusch and Nambisan 2015; Vargo and Lusch 2004). These re-conceptualizations imply three shifts in analyzing a business environment. First, S-D logic moves the spotlight from a single organization to a broader actor-to-actor network - comprising competitors, suppliers, partners, and customers - in which an organization operates (network-centric focus). Second, in economic exchange, goods (as outputs of production and service delivery processes) are no longer the sole object of exchange, but also their associated or stand-alone intangible offerings in which the extent of information content is high (information-centric focus). Third, there is also a shift 


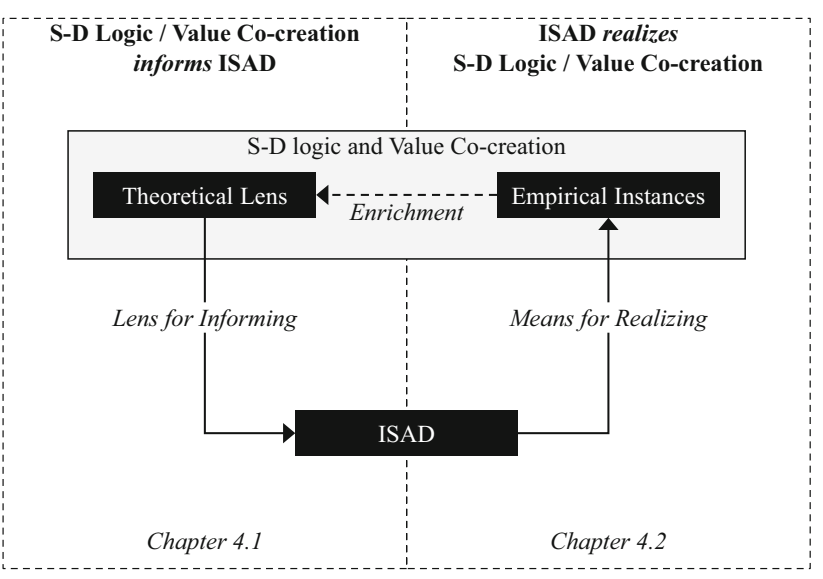

Fig. 1 Mutual relationship between value co-creation (as a lens for informing ISAD) and ISAD (as a means for realizing value cocreation)

in the perception of economic exchange outcomes, from features and attributes of a product/service to the value that is co-created in the given business network (experiencecentric focus) (Lusch and Nambisan 2015). Thus, S-D logic advocates a novel, yet unified, understanding of the nature of the business environment, which entails the need for commencing new discourses in various disciplines (Vargo and Lusch 2016, 2017).

The cumulative effort of bringing S-D logic to the forefront of marketing research has resulted in its core concept of value co-creation as well as value co-creation's related concepts of resource, resource integrator, service ecosystem, and service platform. Table 1 explains and defines these fundamental concepts.

Value co-creation is a process through which actors integrate various types of resources to jointly create value. In response to the equivocal understanding of value cocreation in academic literature, we draw on recent literature reviews, which posit value-in-use as the underlying constituent of value co-creation (Galvagno and Dalli 2014; Ranjan and Read 2016). Value arises through a process of consumption, which is mostly independent of the provider's intervention or exchange. The user's use context and processes including time, location, uncertainties, unique experience, stories, and perceptions determine value-in-use (Macdonald et al. 2016).

To further conceptualize value co-creation, S-D logic elaborates on additional concepts, namely resource, resource integrator, service ecosystem, and service platform (Table 1). Through value co-creation processes, $r e$ sources are integrated. S-D logic re-conceptualizes resources, which "have historically been viewed as those tangible things that humans use for support, often natural resources that are fixed or limited in supply" (Lusch and Nambisan 2015, p. 159). In S-D logic, resource refers to anything that an actor can draw on for support. It comprises both tangible and static (i.e., operand) as well as intangible and dynamic (i.e., operant) resources (Vargo and Lusch 2004). In S-D logic, all actors (e.g., individuals, groups, or organizations) are resource integrators (Lusch and Nambisan 2015). Resource integrators offer resources to other actors (offeror) or benefit from resources that other actors supply (beneficiary). Through the concept of service ecosystem, S-D logic re-conceptualizes the notion of supply chains in terms of actor-to-actor networks in which actors co-evolve their capabilities and roles and that actors depend on one another for their overall effectiveness and survival (Moore 1993). A service ecosystem comprises several service systems and their mutual interactions (Vargo and Akaka 2012). Thus, various service systems engage in service exchange to access, adapt, and integrate resources among themselves. Finally, actors employ service platforms to facilitate their day-to-day resource exchanges and to mutually co-create value. To enhance the efficiency and effectiveness of value co-creation processes, service platforms are configured through modular architectures, comprising both tangible components (e.g., wood, metal, IT hardware, humans) as well as intangible components (e.g., knowledge, skills, experiences, processes, digital artifacts).

\section{Information Systems Analysis and Design}

In promoting S-D logic and its core concept of value cocreation as a new discourse to ISAD research, this section summarizes the main research streams in ISAD and elaborates on how ISAD research can embrace the underpinning premises of S-D logic and value co-creation.

\subsection{Research Streams in Information Systems Analysis and Design}

ISAD comprises two major areas that represent the foundations of this research field (Necco et al. 1987; Iivari et al. 2000, 2004). First, IS analysis aims to gather, analyze, specify, and document IS requirements based on a common understanding that stakeholders have about a real-world domain (Recker et al. 2011). Thus, IS analysis refers to "a number of activities in the early stages of information systems development [...] to identify and document the requirements for an information system to support organizational activities" (Iivari et al. 2006, p. 510). Second, IS design employs techniques to translate requirements into logical IS designs to eventually fulfill the requirements imposed by the real-world domain (Gregor and Hevner 2013). Thus, IS design refers to "the process of defining the system architecture, components, modules, interfaces, and data for a software system to satisfy the requirements 


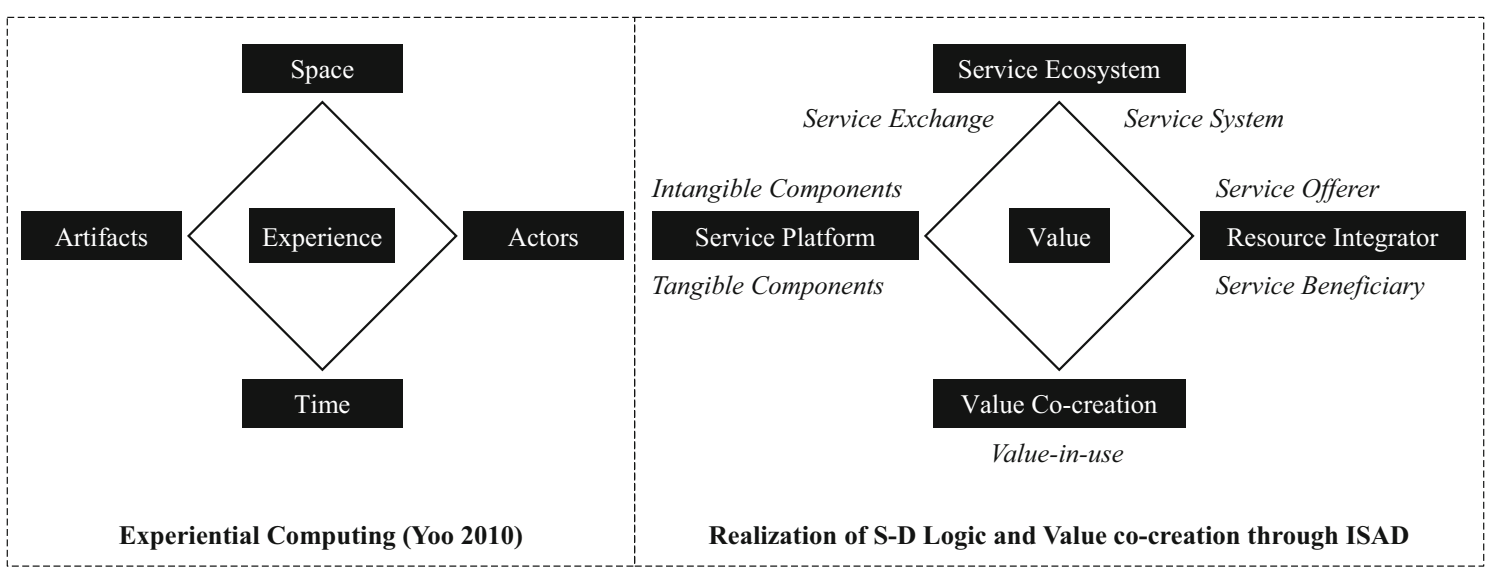

Fig. 2 Conceptual framework for the realization of S-D logic and value co-creation

specified during systems analysis" (Iivari et al. 2006, p. 510).

We distinguish four ISAD research streams (Table 2) by considering studies of influential ISAD scholars (e.g., Necco et al. 1987; Frank 1999; Iivari et al. 2000; Wand and Weber 2002) as well as studies published in the three special issues on ISAD in the leading IS journals (Briggs et al. 2004; Parsons et al. 2005; Iivari et al. 2006). The first stream, ISAD paradigms, is concerned with a set of philosophical (paradigmatic) assumptions and believes that guide our interpretation of reality. For instance, Recker et al. (2011) use an ontological theory to describe and evaluate ontological completeness and ontological clarity of conceptual modeling grammars. The second stream, ISAD approaches, embodies a set of related features (e.g., goals, guiding principles, and fundamental concepts) that drive interpretations and actions in ISAD. Therefore, different ISAD approaches can be distinguished by their, for instance, distinct fundamental concepts such as processes (e.g., Structured Analysis and Design approach), data (e.g., Information Modeling approach), and objects (e.g., ObjectOriented approach). The third stream, ISAD methods, is concerned with a set of activities that are intended to guide the work and cooperation of various stakeholders involved in ISAD endeavors. For instance, Jacobson (1992) offers Object-Oriented Software Engineering (OOSE) as a comprehensive object-oriented ISAD method for developing large-scale industrial IS. It has since evolved into the Rational Unified Process (RUP) method. The fourth stream, ISAD techniques, is concerned with the development of well-defined, reusable procedures to achieve certain outcomes. For instance, the Unified Modeling Language (UML) (Booch et al. 1999) comprises a set of standardized, domain-independent ISAD techniques (e.g., class diagram, object diagram, or activity diagram). Each technique's application results in a partial graphic representation of a system's model. UML's techniques are intended to standardize and unify disparate ISAD techniques underlying the object-oriented ISAD approach.

These four streams are hierarchically interrelated so that ISAD approaches can be grouped into a number of paradigmatic positions. Further, an ISAD approach can be interpreted as a class of specific ISAD methods and, in turn, an ISAD method can be interpreted as a class of specific ISAD techniques (Iivari et al. 2000, 2004). For instance, Object Oriented Software Engineering (OOSE) and Object Oriented Analysis and Design (OOAD) meth$o d s$ associate to the Object-Oriented approach and, in turn, the OOSE method holds several ISAD techniques such as use case diagrams and class models (Iivari et al. 2000, 2004).

Considering the two major phases of ISAD (i.e., IS analysis and design), a substantial part of IS development failures are attributed to problems that arise during the IS analysis phase (Shemer 1987; Castro et al. 2002; Pitts and Browne 2004; Iivari et al. 2006; Lukyanenko and Parsons 2013). In this phase, IS analysts and designers try to make sense of the business environment in which IS are supposed to support organizational practices. Therefore, emergent logics of business should be systematically captured in the IS analysis phase and then need to be translated to IS designs. Nevertheless, due to a lack of attention to theoretical foundations that conceptualize the business logic of IS, many of the ISAD methods and techniques are developed based on common sense and intuition about the nature of the business environment (Siau and Rossi 2011). This results in proposing yet another set of ISAD methods and techniques - called "methodology jungle" by Iivari et al. (2000, p. 182) and "fetish of technique" by Wastell (1996) - most of which lack theoretical foundations to demonstrate their considerable relevance (Siau and Rossi 2011).

By following the latter rationale and with the aim of capturing some of the emerging aspects of contemporary business environments, extant ISAD research calls existing 
ISAD methods and techniques into question and develops new ones. For instance, Lukyanenko and Parsons (2013) argue for the necessity of personalizing customer experiences to better match product and service offerings to individual customer needs (analogous to experience-centric focus of S-D logic). They also argue for the necessity of managing heterogeneous information in a network of interacting organizations (analogous to network-centric focus of S-D logic). Through discussing the abovementioned requirements - imposed by the contemporary business environment - they challenge long-held propositions about conceptual modeling and ask whether traditional conceptual modeling techniques are becoming obsolete. Similarly, other scholars argue that organizations have evolved towards business and service ecosystems (analogous to network-centric focus of S-D logic) and develop, for instance, a new modeling technique (Limonad et al. 2012), an agile business process management life cycle (Bruno et al. 2011), or an ontological model (Lavassani and Movahedi 2017) to account for the contemporary business logic.

These fragmented considerations of contemporary business environments entail a need for a conceptually sound basis to systematically inform new ISAD methods and techniques. This is where the underpinning theoretical foundations of S-D logic can contribute in introducing new ISAD approaches. Through a set of well-defined and unified concepts and premises, S-D logic and its core concept of value co-creation delineate distinct paradigmatic assumptions about business environments and offer a lens to inform complementary and new ISAD approaches. Consequently, new ISAD methods and techniques can be developed to account for new goals (e.g., service-for-service economic exchange), guiding principles (e.g., S-D logic's foundational premises), and fundamental concepts (e.g., service ecosystem, service platform, resource integrator, value co-creation). We thus highlight the pivotal role of theory-informed ISAD approaches to afford a sound basis for developing advantageous ISAD methods and techniques. This brings us to the primary aim of the research note at hand in promoting S-D logic and its core concept of value co-creation as a relevant conceptual basis to advance ISAD research.

\subsection{S-D Logic and Value Co-creation in Information Systems Analysis and Design}

Since S-D logic aims to provide a shared vocabulary across different disciplines (Maglio and Spohrer 2008), it has already been applied in various disciplines such as consumer research (Xie et al. 2008), technology and innovation management (West and Bogers 2014), or institutional economics (Pels and Vargo 2009). By the same token, S-D logic and its core concept of value co-creation have been influential in theorizing IS phenomena.

Most dominantly, extant IS research promotes $S$-D logic and value co-creation as a theoretical lens to study various IS phenomena, such as co-creation of IT/service value (Ceccagnoli et al. 2012; Grover and Kohli 2012; Sarker et al. 2012), strategic alignment (Tallon 2010), business model patterns (Peters et al. 2015), or service-oriented systems (Bardhan et al. 2010). In addition, IS research illustrates and discusses the realization of $S-D$ logic and value co-creation through IT (e.g., Ordanini and Pasini 2008; Yan et al. 2010; Giesbrecht et al. 2016). For the latter, the focus of IS research is often reflected in serviceoriented architecture (SOA) and its related discussions, which are notably guided by the notion of service science. We follow Galvagno and Dalli (2014) in differentiating service science and S-D logic, both of which started and developed in parallel but independent from each other (Vargo et al. 2010; Galvagno and Dalli 2014). Service science literature is neither strictly related to nor grounded in the co-creation debate (e.g., Vargo et al. 2008; Barrett et al. 2015). Our focus lies on S-D logic since it sophisticates the value co-creation concept and complements extant debates of service science (Lusch and Nambisan 2015; Vargo and Lusch 2016).

In offering our view on ISAD through the lens of S-D logic and its core concept of value co-creation, we draw a mutual relationship between value co-creation and ISAD (Fig. 1). We argue that while (1) value co-creation opens up new pathways to analyze and design IS, in turn, (2) ISAD leverages the realization of value co-creation. The latter inevitably provides empirical and practical insights in enriching the theoretical body of value co-creation. Our view thus motivates two main research questions, which call for future research in ISAD.

- First, we motivate prospective research to address the question of how the lens of $S-D$ logic and value cocreation informs ISAD. This research question is in line with existing IS research that promotes S-D logic and value co-creation as a theoretical lens (as outlined earlier in this section) as well with the outlined implications of S-D logic and value co-creation on ISAD (as discussed in Sect. 3.1).

- Second, we motivate prospective research to address the question of how ISAD realizes the shift to $S$-D logic and value co-creation. This research question is in line with extant research in IS concerning the realization of S-D logic and value co-creation through IT (as outlined earlier in this section). It is also in line with recent calls to better understand the nuances of IS as a dynamic and influential resource in value co-creation (Akaka and Vargo 2014). 


\section{Towards Advancing Information Systems Analysis and Design}

Both directions of the abovementioned mutual relationship between value co-creation and ISAD (Fig. 1) are explicated in this section resulting in a research agenda towards advancing ISAD from a value co-creation perspective.

\subsection{Informing IS Analysis and Design by S-D Logic and Value Co-creation}

As discussed in Sect. 3.1, due to its specific paradigmatic assumptions, S-D logic and its core concept of value cocreation offer a new lens to inform complementary and new ISAD approaches and consequently new ISAD methods and techniques. To elaborate on these implications, we build our discussion on Lusch and Nambisan's (2015) perspective on how S-D logic and value co-creation can advance IS research. In effect, focal to value co-creation is the integration of resources (Ranjan and Read 2016). Lusch and Nambisan (2015) hence shed light on the dual roles of IT as both operand and operant resources in value co-creation processes. Therefore, ISAD methods and techniques should account for the dual roles of IT in not only identifying and documenting IS requirements (IS analysis) but also in their implementation (IS design).

IT as Operand Resource: IT as operand resource ensures that the underlying processes of value co-creation are efficiently and effectively facilitated (Lusch and Nambisan 2015). In that sense, IT plays a passive role in enabling actors in their mixing and matching of resources during value co-creation. For instance, IT helps actors establish and maintain a service ecosystem, search for appropriate resources, or bundle and integrate resources and knowledge. Extant instances of IS in organizational practice at best implicitly and fragmentarily offer capabilities to facilitate value co-creation. Therefore, new or augmented ISAD methods and techniques should adequately identify and leverage the implementation of IS requirements that, for instance, capture how IT (1) generates or constrains the diverse forms of value co-creation in service ecosystems; (2) facilitates the dynamic construction, dissemination, search, and identification of resources among diverse sets of actors; (3) supports the different roles of service beneficiaries - as ideator, designer, or intermediary - in experiencing co-created value; and (iv) enhances the transparency of value co-creation activities (i.e., roles, processes, and outcomes) in service exchange. The latter supports actors in sharing their experience, in personalizing a service offer during usage time, and in mediating mutual relationships.
For instance, jet turbine producers employ software as operand IT resource to analyze long-term turbine usage data along different turbine parameters (e.g., pressure, temperature, or vibration). Moreover, jet turbine producers employ on-board sensors and live data feeds during jet turbine usage time to track and monitor the health of their customers' installed base of engines operating worldwide. In close collaboration with the producers, airlines conduct data analysis to reduce fuel consumption and to calculate minimal maintenance downtime (Neely 2008; Fichman et al. 2014; Barrett et al. 2015). Therefore, such a role of IT as operand resource in value co-creation demands ISAD methods and techniques that effectively and efficiently analyze and design real-world instances of value co-creation as illustrated above.

IT as Operant Resource: IT as operant resource plays an active role in triggering or initiating value co-creation and in affecting other actors and their choices (Vargo and Lusch 2004; Akaka and Vargo 2014). In that sense, IT "seek[s] out and pursue[s] unique resource integration opportunities on its own, and in the process, engage[s] with (or act[s] upon) other actors" (Lusch and Nambisan 2015, p. 167). Initial exemplary indications of how IT as an operant resource may manifest are the ways they proactively act in value co-creation. Extant instances of IS in organizational practice, however, may not account for IT as operant resource, since such a role for IT is dynamic in nature and its specificities are yet to be explicated (Lusch and Nambisan 2015) and new IS instances to support such a role are yet to be uncovered (Yoo et al. 2010). Therefore, new ISAD methods and techniques should adequately identify and leverage the implementation of IS requirements that, for instance, capture how IT itself - as an active agent or trigger - will (1) generate and share knowledge, ideas, and creativity; (2) grant and receive control to/from other actors in the service ecosystem; (3) autonomously design and readjust the interfaces of interaction with the given organization and its customers; (iv) personalize service by immersing itself in the context and developing specialized competences; and (v) jointly, reciprocally, and iteratively collaborate with other human and non-human actors during value co-creation processes.

For instance, sensor-based airplane pilot assistance service systems themselves, as operant resource, actively trigger and control jet turbine operations during flight time as a function of weather parameters, aircraft behavior, and pilot behavior to increase flight efficiency (Neely 2008; Fichman et al. 2014; Barrett et al. 2015). Therefore, analyzing and designing use cases of such a role for IT as operan $t$ resource demands ISAD methods and techniques that can capture both extant real-world instances of operant IT in their service system contexts (such as 
illustrated above) as well as innovative use cases in value co-creation that yet need to be discovered.

Regarding the decisive role of IT as both operand and operant resources in value co-creation processes, S-D logic's distinct, yet unified, paradigmatic assumptions on economic exchange provide a fruitful basis to inform new ISAD approaches with their respective new goals, guiding principles, and fundamental concepts. For instance, current ISAD methods and techniques are dominated by process-, data-, and object-oriented ISAD approaches (see Sect. 3.1). These approaches mainly concern efficiency, accuracy, or productivity through IT applications (IT as operand resource). Therefore, ISAD research can be informed by S-D logic's, for instance, value-, resource-, and ecosystem-orientations to offer new ISAD approaches and their associated methods and techniques. The latter is in line with Avital and Te'eni's (2009) outlined IS design considerations (i.e., generative capacity and generative fit) to enhance creativity, generate innovation, and reveal new opportunities through IT applications (IT as operant resource).

\subsection{Realizing S-D Logic and Value Co-creation through IS Analysis and Design}

In the preceding discussion, we elaborated on the contribution of S-D logic and value co-creation in complementing extant views on ISAD. The focus was on S-D logic's perspective on IT, as both operand and operant resources, in value co-creation. In this section, we embed value co-creation in S-D logic's other relevant concepts (i.e., resource integrator, service ecosystem, and service platform, see Table 1) to eventually elaborate on how ISAD can realize the shift to S-D logic and value cocreation.

Relying on the underpinning premises of S-D logic, customer experience is central in co-creating value because, along this co-creation experience, customers can integrate their own resources in the service and determine the ultimate value of the proposed service (Lusch and Nambisan 2015; Vargo and Lusch 2016; Ranjan and Read 2016). Therefore, an experiential approach provides purposeful guidance for conceptualizing how IS should be analyzed in and designed for such business contexts. To this end, we employ the framework of experiential computing developed by Yoo (2010, p. 219) as it (1) focuses on individuals' experience mediated by IT, (2) concerns the experience-based design of IT, and (3) exhaustively provides the conceptual dimensions that need to be considered in realizing experience-based design of IT. This framework posits that IS in general, and digital technology in particular, mediate the four dimensions of human experience namely, time, space, actors, and artifacts (Yoo 2010, p. 213). For the purpose of our paper, we translate this conceptual framework's four dimensions and its core element of experience to our topic of interest (Fig. 2). We translate experience to value - that is, value resides in the core of a conceptual model of value co-creation in IS research. The four dimensions' translation to our topic of interest is explained in the following.

Service Platform: According to Yoo (2010), artifacts are physical, digital, or digitally enabled means through which humans make experience. In S-D logic, service platforms are any kind of artifacts that act as the mediator, enabler, facilitator, or distribution mechanism for service provisioning. For instance, jet turbines are service platforms facilitating the service of airtime. A software for computeraided design is a service platform facilitating the service of turbine design. Notably, recent IS research emphasizes the notion of "digitally enabled service platform" (Lusch and Nambisan 2015, p. 167). Digital and/or digitally enabled service platforms involve new combinations of digital and physical components to create novel market offerings (Yoo et al. 2010). Thus, both IS components (e.g., software for computer-aided jet turbine design) and IS components embedded in non-IS components (e.g., sensors installed in jet turbines) are conceptualized as service platforms (Neely 2008; Fichman et al. 2014; Barrett et al. 2015). We posit that, to experience co-creation of value, IS need to be analyzed and designed to digitally mediate embodied experience of value as a function of service platform (artifact), service ecosystem (space), value co-creation (time), and resource integrators (actors) (Yoo 2010; Lusch and Nambisan 2015). Specifically, digital service platforms can be the focus of prospective IS research due to their relevance and ever-increasing importance. To this end, prospective research is motivated to address how digital service platforms can be analyzed and designed to realize, for instance, appropriate modular architectures with the aim of enhancing dynamic (re-)combination of resources (Lusch and Nambisan 2015, p. 162).

Service Ecosystem: According to Yoo (2010), space is a structure that is created by human experience and actions. In S-D logic, a complex service ecosystem consists of emergent actor-to-actor networks (Akaka et al. 2012; Lusch and Nambisan 2015; Friend and Malshe 2016) as the space in which value is experienced. Under such premise, resources are dynamically integrated by all actors - comprising individuals, groups, organizations, and markets (Sidorova et al. 2008) - in a network of other actors, all being potential co-creators of value. Thus, service ecosystems should be incorporated in ISAD in that digital and digitally enabled service platforms contribute to the realization of service exchange within and between service 
systems. To this end, prospective research is motivated to address how IS can be analyzed and designed to, for instance, realize the diverse forms of collaboration and service exchange in the ecosystem by taking into account the multiplicity, variety, and interdependency of service systems (i.e., structural complexity), and by taking into account the rates and patterns of changes in the ecosystem (i.e., dynamic complexity). For instance, the aviation ecosystem extensively draws on data exchange facilitated by inter-organizational systems to align flight plans and coordinate airplane maintenance prior to take-off.

Resource Integrators: According to Yoo (2010), humans are actors that experience artifacts and other actors. In S-D logic, tangible and intangible resources are integrated by service offerors and service beneficiaries as the actors that offer and experience value, respectively. Thus, resource integrators should be considered in ISAD in that digital or digitally enabled service platforms adequately support actors in efficiently and effectively realizing their service offerings and service benefits. To this end, future research is motivated to address how IS can be analyzed and designed to, for instance, realize actors' searching for and bundling (mixing and matching) resources within and across service platforms. Resource integration, however, may not be a predefined and stable process anymore. Instead, resource integration may be dynamically adjusted all the time and thus requires dynamic adaptations of further elements such as business processes. For instance, airlines, as operators of jet turbines, integrate their resources with travel agents, jet fuel suppliers, and ground handling providers to co-create the eventual mobility service. Since such high levels of differentiation of resource integrators are barely thinkable without IS support, we posit that ISAD needs to reflect such distinct roles of resource integrators. Further, runtime re-configuration and integration of resources to fit the respective service to customers' changing requirements should also be a design consideration.

Value Co-creation: According to Yoo (2010), experience is always a function of time and temporally emergent. Therefore, the time dimension reflects a process through which experience unfolds. In S-D logic, value is co-created through the processes of resource integration as the time along which co-created value emerges. Under such premise, value-in-use is always temporary and in the process of becoming - that is, temporally emergent (Payne et al. 2008). Value-in-use is always uniquely derived from the user's use context (Ranjan and Read 2016). Thus, value cocreation should be embodied in ISAD in that digitally enabled service platforms properly support the realization of processes underpinning resource integration. To this end, prospective research is motivated to address how IS can be analyzed and designed to realize, for instance, customers' aspirations of embedding their experience in the realization of value and personalizing exchanged service during usage time. Since value-in-use is temporary, ISAD needs to support designers to purposefully shape the space of interaction, which is spanned by the resources to be integrated and the time along which co-creation takes place. For instance, airlines increasingly draw on IS in establishing joint, reciprocal, and iterative processes with the airline customers during flight time. Therefore, capturing the dynamism of the runtime context in which valuein-use occurs becomes decisive in the design of such IS.

In this subsection, we discussed some of the novel requirements in the analysis and design of IS to account for the fundamental concepts raised by S-D logic. Since value co-creation from an S-D logic perspective still is a rather new topic in IS research, the discussed novel requirements are provided as some exemplars (for more exemplars see Lusch and Nambisan 2015) serving as a basis to demonstrate how IS contribute in realizing S-D logic and value co-creation in organizational practices. In sum, the offered conceptual framework (Fig. 2) asserts that IS are central in realizing the theoretical assumptions of S-D logic and its core concept of value co-creation. To this end and to effectively experience co-creation of value, ISAD needs to grasp the dynamic collaboration among actors in actor-toactor networks (service ecosystem) to help them integrate and exchange resources (resource integrators) through digital or digitally enabled platforms (service platform). In this regard, digital platforms are central so that their roles as both operand and operant resources should be considered in ISAD. To briefly illustrate how the contemporary business environment requires extended or new ISAD methods and techniques, we employ digital platforms as an exemplary ISAD case. Digital platforms are gaining significant momentum in IS research and practice and have become a novel means to extend the notion of value creation in firms beyond their organizational boundaries (Parker et al. 2017; Reuver et al. 2017). Each digital platform is associated to a service ecosystem comprising the owner of the digital platform as well as other actors such as partners, subcontractors, regulators, and customers. Various actors in the service ecosystem exploit the respective digital platform to integrate their unique resources and to eventually offer a unique value proposition (a service) to a specific customer (Ceccagnoli et al. 2012; Han et al. 2012; Sarker et al. 2012). In that sense, the digital platform owner is merely the provider of the platform, while the platform's survival depends on the quality of value co-creation processes among other actors (Ceccagnoli et al. 2012; Parker et al. 2017). Further, each service is triggered by a customer (reflecting the 
customer's unique and contextual requirements), for which different actors integrate their resources to serve the very specific need of the customer. Therefore, the pertinent digital service ecosystem can be characterized by the dynamic and case-base integration of resources among various actors to provide specific service to particular customers through the digital platform (Eaton et al. 2015). Such an ISAD case is different compared to conventional ISAD cases in terms of the underpinning ISAD approaches and their associated goals, guiding principles, and fundamental concepts (see Sect. 3.1). In this case, the main goal is value co-creation through service-for-service exchange, so that platform partners exploit the owner's platform to develop and offer their service to customers in the respective service ecosystem. Similarly, guiding principles are different in that value is co-created by multiple actors (e.g., owner, partners, and subcontractors), always demanded by and including the beneficiary (i.e., end customer) (Vargo and Lusch 2016). Consequently, fundamental concepts, to be considered in ISAD, are different so that other central concepts (compared to process, data, and object concepts in conventional ISAD approaches) should come to the fore such as value, value co-creation, service, service ecosystem, resource integrators, among the others. Owing to this new ISAD approach's distinct goals, guiding principles, and fundamental concepts, extended or new ISAD methods and techniques are required. As an example, such ISAD methods and techniques should consider the relative, subjective, and experience-based nature of value (Holbrook 2006; Gallarza et al. 2017). That is, resource integration is not limited to "design-time" alone, but during the delivery of a service, changes may occur with regard to, for instance, customer's interventions, availability of resources, and the run-time configuration of the service (eco-)system. Such changes are likely to have an impact on the a priori expected co-creation of value. Therefore, the design of the service delivery, in particular how the value co-creation will materialize, needs to be dynamically adjusted at "run-time". This is, in fact, due to the inherent dynamics of value co-creation processes (Andreu et al. 2010; Gummesson and Mele 2010; Kowalkowski 2011) as well as the subjective nature of the perceived value by the customer (Holbrook 2006; Gallarza et al. 2017).

\section{Conclusion and Research Agenda}

This research note is based on the premise that research in ISAD should account for emergent business logics that require to rethink the way a business environment is conceptualized, and, consequently, the way IS as part of such a business environment are analyzed and designed. Due to the increasing recognition of S-D logic, as a paradigmatic shift away from G-D logic, this research note builds on S-D logic and its core concept of value co-creation to introduce a new discourse and to outline a research agenda for ISAD research. In doing so and by drawing a mutual relationship between value co-creation and ISAD, we motivate prospective research to address the questions of (1) how the lens of $S$-D logic and value co-creation informs ISAD; and (2) how ISAD realizes the shift to $S-D$ logic and value cocreation in practice. In the following, we discuss a research agenda for each of the questions mentioned above and suggest contributions that can be particularly relevant and instrumental in examining the mutual relations between value co-creation and ISAD (Table 3 ).

Concerning the first question, S-D logic and its core concept of value co-creation provide a basis to inform new and complementary ISAD approaches and their corresponding ISAD methods and techniques. Nevertheless, these research endeavors require some preliminary steps towards comprehensive ISAD approaches. More precisely, the attempt to thoroughly reflect S-D logic in ISAD approaches suffers from an equivocal understanding of value co-creation's conceptual boundaries. For instance, McColl-Kennedy et al. (2012) developed a catalogue of 27 different definitions of value co-creation, emphasizing the underlying theoretical ambiguity. Therefore, a multidisciplinary reference vocabulary in the form of an unambiguous S-D logic and value co-creation glossary is not available for ISAD. This void has been raised not only in IS literature (Alter 2012), but also in the reference discipline of S-D logic (i.e., marketing research) (O'Shaughnessy and O'Shaughnessy 2009; Godsiff 2010). Once academia has agreed upon the abovementioned glossary, an ontology would facilitate ontology-driven ISAD (Fonseca and Martin 2007; Chen-Huei Chou et al. 2014). As an ontology is a description of components and their relationships that describe the nature of a domain of discourse (Chandrasekaran et al. 1999), a value co-creation ontology would comprise the meanings of constitutive components of value co-creation and, more importantly, their inherent relationships. There are few studies aiming at one or a few fragmented aspects of value co-creation in ontology development endeavors, for instance, ontological foundation of S-D logic (Fragidis and Tarabanis 2011), core value ontology (Gailly et al. 2016), service system ontologies (Annamalai et al. 2011; Lemey and Poels 2011; Mora et al. 2011), and service science ontology (Lusch et al. 2008). Nevertheless, no such work on a value co-creation ontology from an S-D logic perspective is available. Extant ontologies related to S-D logic or value co-creation either (1) engage in ontology development for value co-creation, but not from an S-D logic perspective; or (2) engage in an S-D logic perspective, but do not focus on value co- 
creation. Thus, an ontology should deal with the general assumptions concerning the explanatory invariants of S-D logic. These assumptions would then provide a framework enabling the understanding and explanation of value cocreation across all research domains (Fonseca and Martin 2007).

Relying on a solid glossary and on an ontology for value co-creation, the next step towards advancing ISAD is the development of ISAD techniques such as a modeling language for value co-creation. In effect, modeling is a core activity in ISAD, which refers to "building a conceptual model of the domain that an IS is intended to support" (Clarke et al. 2016, p. 365). There are a number of modeling languages and frameworks aiming at one or a few fragmented aspects of a language for S-D logic and value (co-)creation, for instance, e3Value (Gordijn and Akkermans 2003) for value modeling, $i^{*}$ (Yu and Mylopoulos 1994) and KAOS (Matulevičius et al. 2007) for goal modeling, as well as ArchiMate (Lankhorst et al. 2009) for general enterprise architecture modeling including service aspects. However, no work on a reference language for modeling value co-creation from an S-D logic perspective is available. Such a modeling language should not only account for the structural aspect of value co-creation (e.g., constructs that represent the domain of interest) but also its behavioral aspect (e.g., dynamics, runtime re-configuration, and context) (Siau and Rossi 2011).

Moreover, due to the novelty and abstractness of value co-creation from an S-D logic perspective, extant research lacks empirical illustrations to demonstrate service thinking in real-world practices. This lack of empirical illustrations hampers the translation of the value co-creation knowledge base to the domain of ISAD. The concept of value co-creation has been discussed for more than a decade (Galvagno and Dalli 2014; Ranjan and Read 2016), but empirical evidences on how service offerors actually interact and exchange resources to co-create value with service beneficiaries are just emerging (e.g., Sarker et al. 2012). Consequently, we lack empirical analyses of how economic actors engage in value co-creation, and, consequently, we have only few guidelines for ISAD on how this process could ideally be realized (Payne et al. 2008). Therefore, conducting case surveys to collect empirical data on value co-creation and making these cases available in a database of value co-creation cases would be a considerable contribution to the respective research community.

In sum, the suggested future research on value co-creation glossary and ontology can be considered as the first steps towards value co-creation-informed ISAD approaches. The value co-creation modeling language, in turn, provides a fruitful ISAD technique in pursuing the respective ISAD approaches. Finally, a further research step is required to bring these efforts together in ISAD methods not only through the conceptual foundations of S-D logic, but also through their empirical manifestations in real-world organizational practices.

Concerning the second question, we posit that the IS community could considerably contribute to materialize the paradigmatic shift underpinning the philosophical reorientation from G-D logic to S-D logic. Relying on the fundamental concepts of S-D logic, examining the second question requires systematic research on digital service platforms as well as on IS-enabled service ecosystems, resource integration, and value co-creation.

Extant IS research has already started investigating this question through demonstrating how SOA realizes value co-creation (Ordanini and Pasini 2008; Yan et al. 2010) or how value co-creation has been reflected in existing IT applications, for instance, in IT-supported citizen advisory services (Giesbrecht et al. 2016). Nevertheless, IS scholars still call for further investigations (Akaka and Vargo 2014) on, for instance, novel aspects of IS that would generate or constrain diverse forms of resource integration; novel mechanisms of IS that enable identification, dynamic construction, and wide dissemination of resources; as well as novel ways of developing digital resources that trigger value co-creation (Lusch and Nambisan 2015). Owing to the mutual relationship between value co-creation and ISAD, the resulted insights from these studies would (1) enrich S-D logic and value co-creation's extant body of knowledge and (2) inform the development of complementary or new ISAD approaches, methods, and techniques. Therefore, the immediate contribution to be particularly relevant in this research question is empirical illustrations on IS-enabled value co-creation. These empirical studies would serve as a basis for not only demonstrating the actual realization of value co-creation through IT applications, but also informing design considerations and the employed methods and techniques in designing such IS-enabled value co-creation instances. Further, those IS instances that enable value co-creation (e.g., digital platforms) are a pivotal means to shape digital service ecosystems comprising various actor roles. Due to the dynamic nature of value co-creation processes and owing to a multitude of actors' engagement (that constantly join or leave the respective ecosystem) in value co-creation processes, such IS instances are considerably different in their design and evolution compared to conventional IS instances (e.g., enterprise systems). One of the mainstream discussions on the specificities of such IS instances is the required balance between control (to centrally stabilize the provision of the requested services) and generativity (to attract as many resources and actors as possible to satisfy diverging requirements of end users) in their design and evolution (Ciborra 2000; Tilson et al. 2010; Henfridsson 
and Bygstad 2013; Eaton et al. 2015; Tan et al. 2015; Reuver et al. 2017). Therefore, delineating design principles for value co-creation-enabling IS instances, with regard to their specificities, would be of considerable value. Such studies would leverage and facilitate the shift to S-D logic and value co-creation through purposefully designed IS instances for value co-creation processes.

Acknowledgements This work has been supported by the Swiss National Science Foundation (SNSF).

\section{References}

Aarikka-Stenroos L, Jaakkola E (2012) Value co-creation in knowledge intensive business services: a dyadic perspective on the joint problem solving process. Ind Mark Manag 41:15-26

Akaka MA, Vargo SL (2014) Technology as an operant resource in service (eco)systems. Inf Syst E Bus Manag 12:367-384

Akaka MA, Vargo SL, Lusch RF (2012) An exploration of networks in value cocreation: a service-ecosystems view. Rev Mark Res 9:13-50

Albert TC, Goes PB, Gupta A (2004) GIST: a model for design and management of content and interactivity of customer-centric web sites. MIS Q 28:161-182

Allen GN, March ST (2012) A research note on representing partwhole relations in conceptual modeling. MIS Q 36:945-964

Alter S (2004) Possibilities for cross-fertilization between interpretive approaches and other methods for analyzing information systems. Eur J Inf Syst 13:173-185. https://doi.org/10.10057/ palgrave.ejis.3000499

Alter S (2012) Challenges for service science. J Inf Technol Theory Appl 13:22

Andreu L, Sánchez I, Mele C (2010) Value co-creation among retailers and consumers: new insights into the furniture market. J Retail Consum Serv 17:241-250

Annamalai G, Hussain R, Cakkol M, et al (2011) An ontology for product-service systems. In: Hesselbach J, Herrmann C (eds) Functional thinking for value creation. In: Proceedings of the $3 \mathrm{rd}$ CIRP international conference on industrial product service systems. Springer, Heidelberg, pp 231-236

Avital M, Te'eni D (2009) From generative fit to generative capacity: exploring an emerging dimension of information systems design and task performance. Inf Syst J 19:345-367. https://doi.org/10. 1111/j.1365-2575.2007.00291.x

Ba S, Stallaert J, Whinston AB (2001) Research commentary: introducing a third dimension in information systems design-the case for incentive alignment. Inf Syst Res 12:225

Bansler JP, Bødker K (1993) A reappraisal of structured analysis: design in an organizational context. ACM Trans Inf Syst 11:165-193. https://doi.org/10.1145/130226.148055

Bardhan IR, Demirkan H, Kannan PK et al (2010) An interdisciplinary perspective on IT services management and service science. J Manag Inf Syst 26:13-64. https://doi.org/10.2753/ MIS0742-1222260402

Baron S, Warnaby G (2011) Individual customers' use and integration of resources: empirical findings and organizational implications in the context of value co-creation. Ind Mark Manag 40:211-218. https://doi.org/10.1016/j.indmarman.2010.06.033

Barrett M, Davidson E, Prabhu J, Vargo SL (2015) Service innovation in the digital age: key contributions and future directions. MIS Q $39: 135-154$
Beirão G, Patrício L, Fisk RP (2017) Value cocreation in service ecosystems. J Serv Manag 28:227-249. https://doi.org/10.1108/ JOSM-11-2015-0357

Booch G, Rumbaugh J, Jacobson I (1999) The unified modeling language user guide, 1st edn. Addison-Wesley Longman, Amsterdam

Breidbach CF, Maglio PP (2016) Technology-enabled value cocreation: an empirical analysis of actors, resources, and practices. Ind Mark Manag 56:73-85

Briggs RO, Nunamaker JF Jr, Sprague RH Jr (2004) Special issue: information systems design - theory and methodology. J Manag Inf Syst 20:5-8

Browne GJ, Parsons J (2012) More enduring questions in cognitive IS research. J Assoc Inf Syst 13:1000-1011

Bruno G, Dengler F, Jennings B et al (2011) Key challenges for enabling agile BPM with social software. J Softw Maint Evol Res Pract 23:297-326. https://doi.org/10.1002/smr.523

Burrell G, Morgan G (1979) Sociological paradigms and organisational analysis, 1st edn. Heinemann Educational Books Ltd., Farnham

Castro J, Kolp M, Mylopoulos J (2002) Towards requirements-driven information systems engineering: the Tropos project. Inf Syst 27:365-389. https://doi.org/10.1016/S0306-4379(02)00012-1

Ceccagnoli M, Forman C, Huang P, Wu DJ (2012) Cocreation of value in a platform ecosystem: the case of enterprise software. MIS Q 36:263-290

Chandrasekaran B, Josephson JR, Benjamins VR (1999) What are ontologies, and why do we need them? IEEE Intell Syst 14:20-26

Chou C-H, Mariam Zahedi F, Huimin Z (2014) Ontology-based evaluation of natural disaster management websites: a multistakeholder perspective. MIS Q 38:997-1016

Ciborra C (2000) From control to drift: the dynamics of corporate information infrastructures. Oxford University Press on Demand

Clarke R, Burton-Jones A, Weber R (2016) On the ontological quality and logical quality of conceptual-modeling grammars: the need for a dual perspective. Inf Syst Res 27:365-382. https://doi.org/ 10.1287/isre.2016.0631

de Reuver M, Sørensen C, Basole RC (2017) The digital platform: a research agenda. J Inf Technol. https://doi.org/10.1057/s41265016-0033-3

Dietz G, Juhrisch M (2012) Negotiating language barriers - a methodology for cross-organisational conceptual modelling. Eur J Inf Syst 21:229-254. https://doi.org/10.1057/ejis.2011.30

Eaton B, Elaluf-Calderwood S, Sørensen C, Yoo Youngjin (2015) Distributed tuning of boundary resources: the case of Apple's Ios service system. MIS Q 39:217-243

Edvardsson B, Tronvoll B, Gruber T (2011) Expanding understanding of service exchange and value co-creation: a social construction approach. J Acad Mark Sci 39:327-339. https://doi.org/10.1007/ s11747-010-0200-y

Fichman RG, Dos Santos BL, Zheng Z (2014) Digital innovation as a fundamental and powerful concept in the information systems curriculum. MIS Q 38:329-353

Fonseca F, Martin J (2007) Learning the differences between ontologies and conceptual schemas through ontology-driven information systems. J Assoc Inf Syst 8:129-142

Fragidis G, Tarabanis K (2011) Towards an ontological foundation of service dominant logic. In: LNBIP, Vol 82. Springer, Heidelberg, pp 201-215

Frank U (1999) Conceptual modelling as the core of the information systems discipline-perspectives and epistemological challenges. In: Haseman DW, Nazareth D, Goodhue D (eds) Proceedings of the fifth America's conference on information systems (AMCIS 99). Milwaukee, pp 695-697 
Frank U (2013) Domain-specific modeling languages: requirements analysis and design guidelines. In: Reinhartz-Berger I, Sturm A, Clark $\mathrm{T}$ et al (eds) Domain engineering. Springer, Heidelberg, pp 133-157

Friend SB, Malshe A (2016) Key skills for crafting customer solutions within an ecosystem: a theories-in-use perspective. J Serv Res 19:174-191. https://doi.org/10.1177/ 1094670515617154

Gailly F, Roelens B, Guizzardi G (2016) The design of a core value ontology using ontology patterns. In: Link S, Trujillo JC (eds) Advances in conceptual modeling ER 2016 workshops, AHA, MoBiD, MORE-BI, MReBA, QMMQ, SCME, and WM2SP, Gifu, Japan, November 14-17, 2016, Proceedings. Springer, Heidelberg, pp 183-193

Gallarza MG, Arteaga F, Del Chiappa G et al (2017) A multidimensional service-value scale based on Holbrook's typology of customer value: bridging the gap between the concept and its measurement. J Serv Manag 28:724-762

Galvagno M, Dalli D (2014) Theory of value co-creation: a systematic literature review. Manag Serv Qual Int J 24:643-683. https://doi.org/10.1108/MSQ-09-2013-0187

Germonprez M, Hovorka D, Gal U (2011) Secondary design: a case of behavioral design science research. J Assoc Inf Syst 12:662-683

Giesbrecht T, Schwabe G, Schenk B (2016) Service encounter thinklets: how to empower service agents to put value cocreation into practice. Inf Syst J 27:171-196. https://doi.org/10. 1111/isj.12099

Godsiff P (2010) Service systems and requisite variety. Serv Sci 2:92-101

Gordijn J, Akkermans JM (2003) Value-based requirements engineering: exploring innovative e-commerce ideas. Requir Eng 8:114-134. https://doi.org/10.1007/s00766-003-0169-x

Gregor S, Hevner AR (2013) Positioning and presenting design science research for maximum impact. MIS Q 37:337-355

Grover V, Kohli R (2012) Cocreating IT value: new capabilities and metrics for multifirm environments. MIS Q 36:225-232

Grünbacher P, Halling M, Biffl S et al (2004) Integrating collaborative processes and quality assurance techniques: experiences from requirements negotiation. J Manag Inf Syst 20:9-29

Gummesson E, Mele C (2010) Marketing as value co-creation through network interaction and resource integration. J Bus Mark Manag 4:181-198

Hadar I, Soffer P (2006) Variations in conceptual modeling: classification and ontological analysis. J Assoc Inf Syst 7:568-592

Han K, Oh W, Im KS et al (2012) Value cocreation and wealth spillover in open innovation alliances. MIS Q 36:291-316

Henfridsson O, Bygstad B (2013) The generative mechanisms of digital infrastructure evolution. MIS Q 37:907-931

Hickey AM, Davis AM (2004) A unified model of requirements elicitation. J Manag Inf Syst 20:65-84

Hirschheim R, Klein HK (1989) Four paradigms of information systems development. Commun ACM 32:1199-1216. https:// doi.org/10.1145/67933.67937

Hirschheim R, Klein HK (1992) Paradigmatic influences on information systems development methodologies: evolution and conceptual advances. Adv Comput 34:293-392. https://doi.org/ 10.1016/S0065-2458(08)60328-9

Hirschheim R, Klein HK, Lyytinen K (1995) Information systems development and data modeling: conceptual and philosophical foundations. Cambridge University Press, Cambridge

Hirschheim R, Klein HK, Lyytinen K (1996) Exploring the intellectual structures of information systems development: a social action theoretic analysis. Acc Manag Inf Technol 6:1-64. https:// doi.org/10.1016/0959-8022(96)00004-5
Holbrook MB (2006) Consumption experience, customer value, and subjective personal introspection: an illustrative photographic essay. J Bus Res 59:714-725

Iivari J (1991) A paradigmatic analysis of contemporary schools of IS development. Eur J Inf Syst Basingstoke 1:249-272. https://doi. org/10.1057/ejis.1991.47

Iivari J, Hirschheim R, Klein HK (1998) A paradigmatic analysis contrasting information systems development approaches and methodologies. Inf Syst Res 9:164-193

Iivari J, Hirschheim R, Klein HK (2000) A dynamic framework for classifying information systems development methodologies and approaches. J Manag Inf Syst 17:179-218. https://doi.org/10. $2307 / 40398498$

Iivari J, Hirschheim R, Klein HK (2004) Towards a distinctive body of knowledge for information systems experts: coding ISD process knowledge in two IS journals. Inf Syst J 14:313-342. https://doi.org/10.1111/j.1365-2575.2004.00177.x

Iivari J, Parsons J, Wand Y (2006) Research in information systems analysis and design: introduction to the special issue. J Assoc Inf Syst 7:509-513

Jaakkola E, Alexander M (2014) The role of customer engagement behavior in value co-creation: a service system perspective. J Serv Res 17:247-261. https://doi.org/10.1177/ 1094670514529187

Jacobson I (1992) Object oriented software engineering: a use case driven approach. Addison-Wesley Professional, New York

Janssen P (2006) A generative evolutionary design method. Digit Creat $17: 49-63$

Kishore R, Sharman R, Ramesh R (2004) Computational ontologies and information systems I: foundations. Commun Assoc Inf Syst $14: 158-183$

Kowalkowski C (2011) Dynamics of value propositions: insights from service-dominant logic. Eur J Mark 45:277-294

Lamb R, Kling R (2003) Reconceptualizing users as social actors in information systems research. MIS Q 27:197-235

Lankhorst MM, Proper HA, Jonkers H (2009) The architecture of the archimate language. In: Halpin T, Krogstie J, Nurcan S et al (eds) Enterprise, business-process and information systems modeling. Springer, Heidelberg, pp 367-380

Larsson R (1993) Case survey methodology: quantitative analysis of patterns across case studies. Acad Manag J 36:1515-1546. https://doi.org/10.2307/256820

Lavassani KM, Movahedi B (2017) Applications driven information systems: beyond networks toward business ecosystems. Int $\mathbf{J}$ Innov Digit Econ IJIDE 8:61-75. https://doi.org/10.4018/IJIDE. 2017010104

Lemey E, Poels G (2011) Towards a service system ontology for service science. In: Kappel G, Maamar Z, Motahari-Nezhad HR (eds) Proceedings of the international conference on serviceoriented computing 2011 (ICSOC 2011). Springer, Heidelberg, pp 250-264

Limonad L, Varshney LR, Oppenheim DV, et al (2012) The WaaSaBE model: marrying WaaS and business-entities to support cross-organization collaboration. In: Proceedings of the 2012 annual service research and innovation institute (SRII) global conference. pp 303-312

Lukyanenko R, Parsons J (2013) Is traditional conceptual modeling going to become obsolete? In: Proceedings of the 12th AIS SIGSAND symposium Provo. Provo, Utah

Lusch RF, Nambisan S (2015) Service innovation: a service-dominant logic perspective. MIS Q 39:155-175

Lusch RF, Vargo SL, Wessels G (2008) Toward a conceptual foundation for service science: contributions from servicedominant logic. IBM Syst J 47:5-14 
Macdonald EK, Kleinaltenkamp M, Wilson HN (2016) How business customers judge solutions: solution quality and value in use. J Mark 80:96-120. https://doi.org/10.1509/jm.15.0109

Maglio PP, Spohrer J (2008) Fundamentals of service science. J Acad Mark Sci 36:18-20

Maglio PP, Vargo SL, Caswell N, Spohrer J (2009) The service system is the basic abstraction of service science. Inf Syst E Bus Manag 7:395-406. https://doi.org/10.1007/s10257-008-0105-1

Matulevičius R, Heymans P, Opdahl AL (2007) Ontological analysis of KAOS using separation of reference. Contemp Issues Database Des Inf Syst Dev 37-54

McColl-Kennedy JR, Vargo SL, Dagger TS et al (2012) Health care customer value cocreation practice styles. J Serv Res 15:370-389

Moore JF (1993) Predators and prey: a new ecology of competition. Long Range Plan 26:159

Mora M, Raisinghani M, Gelman O, Sicilia MA (2011) OntoServSys: a service system ontology. In: Demirkan H, Spohrer JC, Krishna V (eds) The science of service systems. Springer, Heidelberg, pp 151-173

Necco CR, Gordon CL, Tsai NW (1987) Systems analysis and design: current practices. MIS Q 11:461-476. https://doi.org/10.2307/ 248975

Neely A (2008) Exploring the financial consequences of the servitization of manufacturing. Oper Manag Res 1:103-118

Neus A, Scherf P (2005) Opening minds: cultural change with the introduction of open-source collaboration methods. IBM Syst $\mathrm{J}$ 44:215-225

O'Shaughnessy J, O'Shaughnessy NJ (2009) The service-dominant perspective: a backward step? Eur J Mark 43:784-793. https:// doi.org/10.1108/103090560910947043

Olerup A (1989) Socio-technical design of computer-assisted work: a discussion of the ethics and tavistock approaches. Scand J Inf Syst 1:7

Ordanini A, Pasini P (2008) Service co-production and value cocreation: the case for a service-oriented architecture (SOA). Eur Manag J 26:289-297. https://doi.org/10.1016/j.emj.2008.04.005

Parker G, Van Alstyne M, Jiang X (2017) Platform ecosystems: how developers invert the firm. MIS Q 41:255-A4

Parsons J, Iivari J, Hevner AR (2005) Research in information systems analysis and design: introduction to the special theme papers. Commun Assoc Inf Syst 16:40

Payne AF, Storbacka K, Frow P (2008) Managing the co-creation of value. J Acad Mark Sci 36:83-96

Pels J, Vargo SL (2009) Toward a transcending conceptualization of relationship: a service-dominant logic perspective. J Bus Ind Mark 24:373-379

Peters C, Blohm I, Leimeister JM (2015) Anatomy of successful business models for complex services: insights from the telemedicine field. J Manag Inf Syst 32:75-104. https://doi.org/ 10.1080/07421222.2015.1095034

Pitts MG, Browne GJ (2004) Stopping behavior of systems analysts during information requirements elicitation. J Manag Inf Syst 21:203-226

Prahalad CK, Ramaswamy V (2004) Co-creation experiences: the next practice in value creation. J Interact Mark 18:5-14

Ranjan K, Read S (2016) Value co-creation: concept and measurement. J Acad Mark Sci 44:290-315. https://doi.org/10.1007/ s11747-014-0397-2

Recker J, Rosemann M, Green P, Indulska M (2011) Do ontological deficiencies in modeling grammars matter? MIS Q 35:57-79

Rugg G, Eva M, Mahmood A et al (2002) Eliciting information about organizational culture via laddering. Inf Syst J 12:215-229. https://doi.org/10.1046/j.1365-2575.2002.00124.x
Sarker S, Sarker S, Sahaym A, Bjørn-Andersen N (2012) Exploring value cocreation in relationships between an ERP vendor and its partners: a revelatory case study. MIS Q 36:317-338

Sharma S, Conduit J (2016) Cocreation culture in health care organizations. J Serv Res 19:438-457. https://doi.org/10.1177/ 1094670516666369

Shemer I (1987) Systems analysis: a systemic analysis of a conceptual model. Commun ACM 30:506-512

Siau K, Rossi M (2011) Evaluation techniques for systems analysis and design modelling methods - a review and comparative analysis. Inf Syst J 21:249-268. https://doi.org/10.1111/j.13652575.2007.00255.x

Sidorova A, Evangelopoulos N, Valacich JS, Ramakrishnan T (2008) Uncovering the intellectual core of the information systems discipline. MIS Q 32:467-482

Siponen M, Baskerville R, Heikka J (2006) A design theory for secure information systems design methods. J Assoc Inf Syst 7:725-770

Sircar S, Nerur SP, Mahapatra R (2001) Revolution or evolution? A comparison of object-oriented and structured systems development methods. MIS Q 25:457-471

Tallon PP (2010) A service science perspective on strategic choice, IT, and performance in U.S. banking. J Manag Inf Syst 26:219-252. https://doi.org/10.2753/MIS0742-1222260408

Tan B, Pan SL, Xianghua Lu, Huang Lihua (2015) The role of IS capabilities in the development of multi-sided platforms: the digital ecosystem strategy of Alibaba.com. J Assoc Inf Syst 16:248-280

Tilson D, Lyytinen K, Sørensen C (2010) Digital infrastructures: the missing IS research agenda. Inf Syst Res 21:748-759. https://doi. org/10.1287/isre. 1100.0318

Vargo SL, Akaka MA (2012) Value cocreation and service systems (re) formation: a service ecosystems view. Serv Sci 4:207-217

Vargo SL, Lusch RF (2004) Evolving to a new dominant logic for marketing. J Mark 68:1-17. https://doi.org/10.1509/jmkg.68.1.1. 24036

Vargo SL, Lusch RF (2008) Service-dominant logic: continuing the evolution. J Acad Mark Sci 36:1-10

Vargo SL, Lusch RF (2016) Institutions and axioms: an extension and update of service-dominant logic. J Acad Mark Sci 44:5-23

Vargo SL, Lusch RF (2017) Service-dominant logic 2025. Int J Res Mark 34:46-67. https://doi.org/10.1016/j.ijresmar.2016.11.001

Vargo SL, Maglio PP, Akaka MA (2008) On value and value cocreation: a service systems and service logic perspective. Eur Manag J 26:145-152

Vargo SL, Lusch RF, Akaka MA (2010) Advancing service science with service-dominant logic. In: Maglio PP, Kieliszewski CA, Spohrer JC (eds) Handbook of service science. Springer, Heidelberg, pp 133-156

Vidgen R (2002) Constructing a web information system development methodology. Inf Syst J 12:247-261. https://doi.org/10. 1046/j.1365-2575.2002.00129.x

Waller V, Johnston RB, Milton SK (2008) Investigating the epistemological stances implicit in ISAD approaches. J Enterp Inf Manag 21:125-138. https://doi.org/10.1108/ 17410390810851381

Wand Y, Weber R (1993) On the ontological expressiveness of information systems analysis and design grammars. Inf Syst $\mathbf{J}$ 3:217-237. https://doi.org/10.1111/j.1365-2575.1993.tb00127.x

Wand Y, Weber R (2002) Research Commentary: information systems and conceptual modeling — a research agenda. Inf Syst Res 13:363-376. https://doi.org/10.1287/isre.13.4.363.69

Wang S, Wang H (2012) Information systems analysis and design. Universal Publishers, Boca Raton

Warren L, Adman P (1999) The use of critical systems thinking in designing a system for a university information systems support 
service. Inf Syst J 9:223-242. https://doi.org/10.1046/j.13652575.1999.00058.x

Wastell DG (1996) The fetish of technique: methodology as a social defence. Inf Syst J 6:25-40. https://doi.org/10.1111/j.1365-2575. 1996.tb00003.x

West J, Bogers M (2014) Leveraging External sources of innovation: a review of research on open innovation. J Prod Innov Manag 31:814-831. https://doi.org/10.1111/jpim.12125

Wilden R, Akaka MA, Karpen IO, Hohberger J (2017) The evolution and prospects of service-dominant logic: an investigation of past, present, and future research. J Serv Res. https://doi.org/10.1177/ 1094670517715121

Xie C, Bagozzi RP, Troye SV (2008) Trying to prosume: toward a theory of consumers as co-creators of value. J Acad Mark Sci 36:109-122

Yan J, Ye K, Wang H, Hua Z (2010) Ontology of collaborative manufacturing: alignment of service-oriented framework with service-dominant logic. Expert Syst Appl 37:2222-2231. https:// doi.org/10.1016/j.eswa.2009.07.051

Yoo Y (2010) Computing in everyday life: a call for research on experiential computing. MIS Q 34:213-231

Yoo Y, Henfridsson O, Lyytinen K (2010) The new organizing logic of digital innovation: an agenda for information systems research. Inf Syst Res 21:724-735. https://doi.org/10.1287/isre. 1100.0322

Yourdon E (1988) Modern structured analysis, 1st edn. Prentice Hall, Englewood Cliffs

Yu ESK, Mylopoulos J (1994) Using goals, rules, and methods to support reasoning in business process reengineering. In: Proceedings of the twenty-seventh Hawaii international conference on system sciences, pp 234-243 